\title{
Value of Morphometry in the Prognosis of Laryngeal Neoplasms
}

\author{
Valores de Morfometría en el Pronóstico de Neoplasmas Laríngeos \\ João Armando Padovani Junior; Reinaldo Azoubel; Alex Tadeu Martins, \& José Victor Maniglia
}

\begin{abstract}
PADOVANI JR. J. A.; AZOUBEL, R.; MARTINS, A . T. \& MANIGLIA, J. V. Value of morphometry in the prognosis of laryngeal neoplasms. Int. J. Morphol., 23(3):275-278, 2005.

SUMMARY: Laryngeal neoplasms represent $2 \%$ of all human cancers. They befall mainly the male sex, especially between 50 and 70 years of age, but exceptionally may occur in infancy or extreme old age. Their occurrence has increased considerably inclusively due to progressive population again. The present work aims at establishing a relation between this infirmity and its prognosis in patients submitted to the treatment recommended by Departament of Otolaryngology and Head Neck Surgery of the School of Medicine of São José do Rio Preto. To this effect, by means of karyometric optical microscopy, cell nuclei in the glottic region of 20 individuals, divided into groups according to their tumor stage and time of survival, were evaluated. Following comparation with a control group and statistical analsis, it became possible to verify that the lesser diameter of nuclei is of prognostic value for initial tumors in this region.
\end{abstract}

KEY WORDS: Morphometry; Laryngeal neoplasms.

\section{INTRODUCTION}

Laryngeal carcinoma is a disease undergoing progressive increase over the last decades; its occurrence falls into the group of major sites of primary cancer, diagnosed in men and women (Globocan, 2001). Although the prevention of risk factors and ever more precocious diagnoses have reduced is prevalence, population aging has limited such reduction.

Laryngeal malignant tumors represent $2 \%$ of all cancer tumors. They befall mainly the male sex, in special individuals between 50 and 70 years of age (Lawson et al.,1991; Noronha, 1989) but are exceptionally found in infancy and extremely old age. Among individuals development of this pathology, over $90 \%$ are inveterate smokers with a concomitant habit of alcoholism. Other factors may be related to the development of this class tumors, such a gastro-esophageal reflux, intoxication by heave metals and irritating substances like carbon monoxide, and viral infections, like the papiloma virus (HPV) (Flanders et al., 1984; Olsen, 1984; Mathe, 1985; Maccomb et al.,1967). Among the laryngeal neoplasms, epidermóide glottic carcinomas are the most frequent ones, constituting approximately 60 to $65 \%$ of cases (Hanna et al.,1998). They present a precocious symptom, hoarseness, and a late dissemination of a restricted amount of lymphatic vessels over the region, in general nodular or infiltrating, of white color due to intensive keratinization, and of rigid consistence. Over time, glottic tumors tend to attain the opposite vocal fold trough the anterior commissure, becoming capable of affecting the posterior arytenoid region. On the upper part, the may attain the superglottic region. In some cases, there may occur an initial damage to the thyroid cartilage and subsequently, to the soft tissues of the neck.

Prognosis in patients showing head and neck cancers, is based on Sobin's (TNM) classification (Sobin et al.,1997), provided by the Union Internationale Contre le Cancer. Howewer, patients at a similar stage and treated in the same way do not necessarily present a similar clinical evolution.

Although many researchers have utilized morphometry to characterize tissue alterations and diagnoses diseases, this methodology has been little utilized by pathologists in clinical practive (Lawrence,1996). Quantitative studies on squamous cells of the head neck used to establish diagnosis and prognosis are scarce in the literature. 
Considering the non-existence of work focusing on morphometry and the diagnosis and prognosis of laryngeal cancer in its glottic segment, a study having the following objectives appears to be justified:

1. To establish the relationship between morphometric data and the diagnosis of laryngeal cancer;

2. To correlate morphometry with the prognosis for carries of glottic carcinoma.

\section{CASUISTICS AN METHOD}

Following the acquiescence of the Committee of Ethics in Reserch of the Medicine of São José do Rio Preto, SP, five groups of patients were studied: four groups originated from individuals carrying laryngeal carcinoma and one was considered as control.

In a prospective, aleatory study, biological material from 20 patients presenting epidermóide carcinoma of the glottis treated at the Department of Otolaryngology and Head and Neck Surgery of the FAMERP, over the period from January 1991 to December, 2002, with a not less than fiveyear period of follow up, was examined. The histology material of these patients was divided into four groups, each composed to five elements, according to their type of tumor stage and responses to the treatment to which they had been submitted. The groups may be visualized in the Table I.

\begin{tabular}{cccc} 
Group & Stage & Treatment & Survival \\
\hline I & T1N0M0 & Radiotherapy exclusively & 5 years \\
II & T3N0M0 & Total laryngectomy and radiotherapy & 5 years \\
III & T1N0M0 & radiotherapy exclusively & 5 years \\
IV & T3NoMo & Total laryngectomy and radiotherapy & 5 years \\
\hline
\end{tabular}

The control group was formed by biopsies of normal larynx of cadavers obtained from the Department of Pathology and Forensic Medicine of the FAMERP. All patients and cadavers were of the male sex, smokers and aged between 38 and 71 years.

The material from tumor-bearing groups, was obtained from biopsies performed by direct laryngoscopy for diagnosis and verification of the tumor stage. Samples from the five groups were immersed in 10\% formaldehyde for subsequent inclusion in paraffin. Ten $5 \mu \mathrm{m}$ sections each, were obtained from each bloc and dyed with hematoxylin/ eosin.

Fifty nuclei from the glottis of each patient were selected and evaluated by optic microscopy under a light (Leica) chamber at 1240x enlargement. Ellipsoid structures only, were contoured on white sulfite paper with a black, $\mathrm{N}^{\circ}$ 2 pencil, and from the determination with a millimeter ruler of the larger (D) and the smaller (d) diameters, the following kariometric parameters were obtained using the software developed by the Department of Stomatology of the FORPUSP (Campos, 2002).

For statistical anaysis, cariometric parameters of the different groups, wee statiscally confronted by means of the non-parametric Kruskal-Wallis test, and their medians compared by Dunn's Multiple Comparisons post-test. P values were considered to be significant when $<0.05$ (alpha error of $5 \%)$.

\section{RESULTS AND DISCUSSION}

Comparisons between the kariometric variables, greater diameter, lesser diameter, mean diameter, volume, area. Perimeter, volume/area, greater diameter/ lesser diameter, eccentricity, contour index and form coefficient among the different groups studied, are shown in the following Table II.

On observing the Table II, a statistically significant difference between several karyometric parameters $\mathrm{cn}$ be noted when groups were compared with each other. However, the results were especially important for the confirmation of malignity in the histological sections of the larynx, since all groups carrying the tumor (G1,G2,G3 and G4) when compared to the control group (G5), showed a statiscally significant difference for the great diameter/lesser diameter parameter relationship, for eccentricity, index of contour and form coefficient.

One seen therefore, that there exists an alteration of the nuclear form in the elements that compose the tumorbearing groups of the tissues evaluated, and that such nuclear deterioration is probably related to the inadequate synthesis of DNA, RNA and/or cell metabolism proteins.

In agreement with the results, the parameter lesser diameter offers an important subsidy for the discrimination of survival in groups with stages T1N0M0 ( G1 and G3) and T3N0M0 ( $\mathrm{G} 2$ and G4), upon comparison between groups G1 and $\mathrm{G} 3$, or when one compares group $\mathrm{G} 2$ with G4. One notes the occurrence of a statiscally significant difference, but only in stage T1N0M0 was it possible to detect individuals that had a survival time higher than 5 years and those that did not ave it. This situation is due to the fact that in individuals having a higher survival time, the lesser diameter was no statistically 
Table II. Comparisons between the kariometric variables among the different groups studied.

\begin{tabular}{|c|c|c|c|c|c|c|c|c|c|c|}
\hline & G1 x G5 & G3 x G5 & G2 $\times$ G5 & G4 x G5 & G1 x G3 & G2 $\times$ G4 & G1 x G2 & G4 $x$ G3 & G1 x G4 & $\mathrm{G} 3 \times \mathrm{G} 2$ \\
\hline Greatest nuclear diameter $(\mu \mathrm{m})$ & $\mathrm{p}<0,001$ & $\mathrm{p}<0,01$ & $\mathrm{p}<0,001$ & $\mathrm{p}<0,001$ & NS & $\mathrm{p}<0,001$ & $\mathrm{p}<0,001$ & $\mathrm{p}<0,001$ & $\mathrm{p}<0,001$ & $\mathrm{p}<0,001$ \\
\hline Smallest nuclear diameter $(\mu \mathrm{m})$ & NS & $\mathrm{p}<0,05$ & $\mathrm{p}<0,05$ & $\mathrm{p}<0,001$ & $\mathrm{p}<0,05$ & $\mathrm{p}<0,001$ & $\mathrm{p}<0,05$ & $\mathrm{p}<0,001$ & $\mathrm{p}<0,001$ & $\mathrm{p}<0,001$ \\
\hline Mean tubular diameter $(\mu \mathrm{m})$ & NS & NS & $\mathrm{p}<0,001$ & $\mathrm{p}<0,001$ & NS & $\mathrm{p}<0,001$ & $\mathrm{p}<0,001$ & $\mathrm{p}<0,001$ & $\mathrm{p}<0,001$ & $\mathrm{p}<0,001$ \\
\hline Nuclear volume $\left(\mu \mathrm{m}^{3}\right)$ & NS & NS & $\mathrm{p}<0,001$ & $\mathrm{p}<0,001$ & NS & $\mathrm{p}<0,001$ & $\mathrm{p}<0,001$ & $\mathrm{p}<0,001$ & $\mathrm{p}<0,001$ & $\mathrm{p}<0,001$ \\
\hline Nuclear area $\left(\mu \mathrm{m}^{2}\right)$ & NS & NS & $\mathrm{p}<0,001$ & $\mathrm{p}<0,001$ & NS & $\mathrm{p}<0,001$ & $\mathrm{p}<0,001$ & $\mathrm{p}<0,001$ & $\mathrm{p}<0,001$ & $\mathrm{p}<0,001$ \\
\hline Nuclear perimeter $(\mu \mathrm{m})$ & NS & NS & $\mathrm{p}<0,001$ & $\mathrm{p}<0,001$ & NS & $\mathrm{p}<0,001$ & $\mathrm{p}<0,001$ & $\mathrm{p}<0,001$ & $\mathrm{p}<0,001$ & $\mathrm{p}<0,001$ \\
\hline Volume/area ratio & NS & NS & $\mathrm{p}<0,001$ & $\mathrm{p}<0,001$ & NS & $\mathrm{p}<0,001$ & $\mathrm{p}<0,001$ & $\mathrm{p}<0,001$ & $\mathrm{p}<0,001$ & $\mathrm{p}<0,001$ \\
\hline Greatest/smallest diameter ratio & $\mathrm{p}<0,01$ & $\mathrm{p}<0,001$ & $\mathrm{p}<0,001$ & $\mathrm{p}<0,001$ & NS & NS & NS & NS & NS & NS \\
\hline Eccentricity & $\mathrm{p}<0,01$ & $\mathrm{p}<0,001$ & $\mathrm{p}<0,001$ & $\mathrm{p}<0,001$ & NS & NS & NS & NS & NS & NS \\
\hline Nuclear shape coefficient & $\mathrm{p}<0,01$ & $\mathrm{p}<0,001$ & $\mathrm{p}<0,001$ & $\mathrm{p}<0,001$ & NS & NS & NS & NS & NS & NS \\
\hline Contour index & $\mathrm{p}<0,001$ & $\mathrm{p}<0,001$ & $\mathrm{p}<0,001$ & $\mathrm{p}<0,001$ & NS & NS & NS & NS & NS & NS \\
\hline
\end{tabular}

G1 - Group 1 - T1N0M0 exclusive radiotherapy treatmento + life spam of 5 years; G2 - Group 2 - T3N0M0 + total laryngectomy + radiotherapy + life spam of 5 years; G3 - Group 3 -T1NOM0 + exclusive radiotherapy + life spam under 5 years; G4 - Group 4 - T3N0M0 + total laryngectomy + radiotherapy + life spam under 5 years; G5 - Group 5 - control groups, normal larynx; $\mathrm{p}<0.05$ significant.

different from that of the control group, while the patients that had a lower survival time presented this karyometric measurement differing compared to controls. Thus, the diameter cited becomes consolidated as a trustworthy parameter regarding the patient's survival time.

This information, related to the prognostic factor supplied by the lesser diameter, agrees with the study by Dobros et al., 2002, who verified that alteration of axis cited, corresponds to the worst prognosis for the presence of metastic nodules.

At present, due to the precocious diagnosis and intervention in glottic cancers, it becomes necessary to utilize quantitative methods to help treatment of the patient. As seen in study, the lesser axis corresponds to the differential prognosis for the group of initial tumors (G1 and G3).
Therefore, we believe that the morphometric method based on the smaller (lesser) diameter. Is a valuable tool that aside from it ease of application, aids the interpretation and elaboration of plans for more specific treatment for patients with initial cancer.

Based on the results obtained, it can be concluded that in patients presenting laryngeal carcinoma:

1. The parameter of the ratio between greater diameter/lesser diameter, eccentricity, form coefficient and contour index are of great importance for the confirmation of neoplasy in the region studied.

2. The lesser diameter presents prognostic value for initial glottic tumors.

PADOVANI JR. J. A.; AZOUBEL, R.; MARTINS, A. T. \& MANIGLIA, J. V. Valores de morfometría en el pronóstico de neoplasmas laríngeos. Int. J. Morphol., 23(3):275-278, 2005.

RESUMEN: Los neoplasmas laríngeos representan el $2 \%$ de todos los cánceres humanos. Ellos ocurren principalmente en el sexo masculino, especialmente entre los 50 y 70 años de edad, pero excepcionalmente pueden producirse en la infancia o en la ancianidad. Esta ocurrencia se ha incrementado considerablemente haciéndose progresiva en la población. El presente trabajo tiene como objetivo establecer una relación entre esta enfermedad y su pronóstico, en pacientes sometidos al tratamiento recomendado por el Departamento de Otorrinolaringología y Cirugía de Cabeza y Cuello de la Escuela de Medicina de São José do Rio Preto, Brasil. Para estos efectos, fueron evaluados, por mediciones cariométricas de microscopía óptica, núcleos celulares, en la región glótica de 20 individuos, divididos en grupos de acuerdo al estado del tumor y tiempo de sobrevida. Se establecieron comparaciones con un grupo control y se efectuaron análisis estadísticos, verficándose que el menor diámetro de los núcleos es de valor pronóstico para tumores iniciales en esta región.

PALABRAS CLAVE: Morfometría; Neoplasmas laríngeos. 


\section{REFERENCES}

Campos, G. M. Programa GMC basic software Pesquisa Biologica, versão 8.1. Faculdade de Odontologia de Ribeirão Preto da Universidade de São Paulo. 2002; http:/ www.forl.usp.br/restauradora/gmc/gmc.html.

Dobros, W.; Gil, K.; Rys, J. \& Stanisz-Wallis, K. Nuclear morphometry for the prediction of regional lymph nodes metastases in patients with cancer of the larynx. Otolaryngology-Head Neck Surg., 123:770-4, 2000.

Flanders, W. D.; Cann, C.; Rothman, K. J. et al. WorkRelated risck factorrs for laryngeal cancer. Am. J. Epidemiol., 119(11):23-32, 1984.

Globocan 2000 - Cancer Incidence. Mortality and Prevalence Wordwide. Version 1.0. IARC Cancerbase. $\mathrm{N}^{\mathrm{o}}$ 5. Lyon, IARC, 2001.

Hanna, E. \& Suen, J. Y. Larynx. In: Close, L. G.; Larson, D. L. \& Shah, J. L. Essentials of head and neck oncology. New York, Thieme, 1998. pp. 223-9.

Lawrence, D. T. Morphometric application in anatomic pathology. Hum. Pathol., 27(5):450-67, 1996.

Lawson, W. \& Billis, H. F. Câncer of the larynx. In: Cancer of the head and neck. James, Y.; Suen Eugene \& Myers, N. Churchill Livingstone, 1991. pp. 434-6,

Maccomb, W. S. \& Fletcher, C. H. Cancer of the head and neck. Baltimore, Williams \& Wilkins, 1967. pp. 246-7.
Mathe, G. Prevention of genitor-anal and buco-laryngoesophageal cancers caused by sexually transmitted viruses. Biomed. Phamacother., 39(6):253-62,1985.

Noronha, M. J. R. Tumores malignos da laringe. In: Cirurgia de Cabeça e Pescoço. Lenine, GB, Alberto, RF. Livraria Rocca, 1989. Vol I. pp.395-6.

Olsen, J. \& Salroe, S. Ocupational causes of laryngeal cancer. J. Epidemiol. Community-Health, 38(2):117-21, 1984.

Sobin, L. H. \& Fleming, I. D. TNM Classification of malignant tumors. 5. ed. Union Internationale Contre le Cancer and the American Joint Committie on Cancer. Cancer, 80(9):1803-4, 1997.

Correspondence to:

Dr. João Armando Padovani Júnior

Faculdade de Medicina de São José do Rio Preto

Av. Brigadeiro Faria Lima, 5416

CEP 15.090-000

São gosé do Rio Preto

São Paulo

BRASIL

Received: 03-05-2005

Accepted: 30-06-2005 